\title{
TRAF2 Gene
}

National Cancer Institute

\section{Source}

National Cancer Institute. TRAF2 Gene. NCI Thesaurus. Code C28653.

This gene is involved in signal transduction and inhibition of apoptosis. 